\title{
Quality Parameters of Raw Milk, SueroCosteño and QuesoCosteño of Municipalities Villanueva and Santa Rosa - Colombia
}

\author{
Diofanor Acevedo ${ }^{\# 1}$, Luis Beltran-Cotta ${ }^{\# 2}$, Marlene Durán ${ }^{* 3}$ \\ \#Department of Food Engineering, School of Engineering, Research Group Innovación y \\ DesarrolloAgropecuario, Agroindustrial(IDAA), Universidad de Cartagena, Av. El Consulado, St. 30 No. 48- \\ 152. Cartagena de IndiasD. T. y C., -Colombia \\ *School of Medicine, Zaragocilla Campus, Universidad de Cartagena, 130015 Cartagena de Indias, D. T. y C.- \\ Colombia. \\ ${ }^{1}$ dacevedoc1@unicartagena.edu.co, ${ }^{2}$ lbeltrancotta@gmail.com, ${ }^{3}$ mduranl@unicartagena.edu.co
}

\begin{abstract}
Thanks to raw cow's milk, Queso Costeño and Suero costeño for the nutrients these possess and to their availability are products very consumed in the Colombian Atlantic Coast; the production of these by-products in the region are mainly not technified and produced in an artisanal way. Therefore, the objective of this research was to determine and contrast the physicochemical parameters of raw cow's milk, Queso Costeño and Suero Costeño from the municipalities of Villanueva and Santa Rosa in the Department of Bolívar-Colombia. The methods of production of Queso Costeño and Suero Costeño were observed in both municipalities, then samples of these were taken and physicochemical tests were carried out. The Queso Costeño and Suero Costeño from Villanueva presented the best results in the parameters of protein, moisture and total solids. The statistically significant differences in the production of milk byproducts assessed were due to differences in the production method of each product.
\end{abstract}

Keyword: quality, fermentation, by-products, production

\section{INTRODUCTION}

The milk is the mammary secretion that comes from mammals, which is obtained from milking.It is also considered an emulsion of fatty matter in aqueous solution.This food is consumed in liquid form or with further processing as dairy products [1][2].Some of the most consumed dairy products that are part of the basic products in the Caribbean Region of Colombia are Queso and Suero costeño, given its easy acquisition and being an important source of protein [3].

Queso Costeño is a traditional cheese from the Departments of Bolívar, Atlántico, Córdoba, Sucre, La Guajira, Magdalena and Cesar,even though it has reached dairy areas such as La Sabanaof Bogota and the Llanos orientales.This food is made from raw milk, also this is important in the regional economy and is part of the family basket in the previously mentioned departments.It has special characteristics such as freshness, hard texture, some eyes and high salt content [4]-[6].Queso Costeño can be of two types: kneaded and chopped.They have some eyes, their outward appearance, brightness and the equipment used are similar.The chopped cheese meat has a hard, dry texture that does not break easily when rubbed between hands. The kneaded cheese is moderately hard, releases little serum and melts easily when rubbed between hands[7][8].

Another of the milk by-products is the Suero Costeño, this product is made from raw cow's milk with acid whey through natural acidification by the action of native microorganisms,this food isalso traditionally produced and consumed in the Atlantic Coast of Colombia.It has a viscous consistency, thanks to the concentration of total solids (32.01\% average).In addition to the native microorganisms, another factor helps to obtain the characteristics of the product, such as the temperature of the region in which it is produced (approximately 28 ${ }^{\circ} \mathrm{C}$ ). The time of the entire process for Suero Costeñotakes between 1 and 3 days, depending on the desired viscosity.This is differentiated from other fermented dairy products by the addition of common salt $(\mathrm{NaCl})$, which can reach up to $3 \%$ concentration in the final product[9]-[12].

The production of both Queso Costeño and Suero Costeño in the Colombian Atlantic Region is not technified, mainly carried out in a traditional manner and with different procedures [13].Therefore, some authors such as Granados et al., [14], Gonzalez-Morelo et al., [15], Chaves and Romero [16], Ballesta[17] and Jiménez et al., [18] have studied the physicochemical characteristics of these products and thus evaluated their quality in different places on the Atlantic coast.For this reason, the objective of this research was to determine the physicochemical parameters as quality parameter of raw cow's milk, Queso Costeño and Suero Costeño from the municipalities of Villanueva and Santa Rosa in the Department of Bolívar-Colombia. 


\section{MATERIALS AND METHODS}

\section{A. Production of QuesoCosteño and Suero Costeño from the municipality of Santa Rosa}

In the production of theQuesocosteño, the industrial rennet was first added to the filtered milk in proportions of $3 \mathrm{~g}$ of rennet per $100 \mathrm{~L}$ of milk, this mixture was homogenized and the rennet enzymes were left to act for 45 min at room temperature $\left(30^{\circ} \mathrm{C}\right)$. Later, the curd was cut manually and left $10 \mathrm{~min}$ for the whey or espiche to be released and removed with the help of utensils.The addition of sodium chloride was added directly to $8 \%$ in relation to the amount of cheese and was kneaded by hand to distribute it homogeneously; it was then molded, mechanically pressed and stored at temperatures between 4 and $8{ }^{\circ} \mathrm{C}$.

For the production of the Suero costeño, the milk was first received, filtered and left to rest. It was fermented with the microbial flora typical of milk for $7 \mathrm{~h}$.Then it was mixed and waited $10 \mathrm{~h}$, then filtered to separate the espiche(liquid fraction) and the clot or semi-solid part. Sodium chloride, water, and water were added to the clot and beaten. It was finally stored at $5^{\circ} \mathrm{C}$.

\section{B. Production of Queso Costeño and Suero Costeño from the municipality of Villanueva}

The production of the QuesoCosteñoofVillanueva is similar to that produced in the municipality of Santa Rosa, with the difference that after mechanical pressing, it is compressed with the hands and kneaded to remove espiche that was still present, after this is stored at temperatures between 4 and $8{ }^{\circ} \mathrm{C}$.For the production of Suero Costeño, filtered milk was used and mixed with espiche resulting from the production process ofQuesocosteño, was fermented with the native flora of milk for 7.5 - 8 h.The semi-solid part was then separated from the resulting espiche. The semi-solid part was added sodium chloride and beaten, finally stored at $5^{\circ} \mathrm{C}$.

\section{Sample collection}

In the towns of Villanueva and Santa Rosa were visited places where milk,Suerocosteñoand QuesoCosteñoare sold. Three samples of $500 \mathrm{~mL}$ of raw milk and SueroCosteño and $500 \mathrm{~g}$ of Queso Costeño were taken from each town. The samples were coded and transported in refrigerated recipients to the laboratory.

\section{Physicochemical analysis of raw milk, SueroCosteño andQuesoCosteño}

The physicochemical analyses performed on raw milk, Suero costeño andQuesocosteño were: protein (AOAC 984.13), fat (AOAC 929.39 C), moisture (AOAC 927.05), ash (AOAC 923.03), total solids (Gravimetry), calcium (EAA-Llama), zinc (EAA-Llama) and phosphorus (AOAC 995.11).

\section{E. Statistical analysis}

Statistical analysis of the data was performed using the statistical software STATGRAPHICS centurion XVI.I using testsanalysis of variance (ANOVA) with a 95\% confidence interval. All trials were performed in triplicate.

\section{RESULTS AND DISCUSSION}

Table 1 shows the results of the physicochemical analysis that were carried out in the two municipalities in question, where it can be observed that there was only a statistically significant difference $(p<0.05)$ in the parameters of ash, calcium, zinc and phosphorus between the two raw milk samples.Given these results, it can be said that both Villanueva raw milk and Santa Rosa milk meet the minimum requirements of Colombian Technical Standard (NTC) 399[19] in the parameters of total solids and fat.

Table I. Physicochemical results of Villanueva and Santa Rosa raw cow milk

\begin{tabular}{|l|c|c|}
\hline Type of test & Villanueva & Santa Rosa \\
\hline Protein (\%) & $3,93 \pm 0,06^{\mathrm{a}}$ & $3,87 \pm 0,05^{\mathrm{a}}$ \\
\hline Fat (\%) & $3,67 \pm 0,06^{\mathrm{a}}$ & $3,61 \pm 0,06^{\mathrm{a}}$ \\
\hline Moisture (\%) & $87,21 \pm 0,28^{\mathrm{a}}$ & $87,5 \pm 0,26^{\mathrm{a}}$ \\
\hline Ash (\%) & $0,61 \pm 0,03^{\mathrm{a}}$ & $0,40 \pm 0,02^{\mathrm{b}}$ \\
\hline Total solids (\%) & $12,19 \pm 0,17^{\mathrm{a}}$ & $12,5 \pm 0,26^{\mathrm{a}}$ \\
\hline Calcium (\%) & $0,21 \pm 0,005^{\mathrm{a}}$ & $0,19 \pm 0,01^{\mathrm{b}}$ \\
\hline Zinc (mg) & $2,12 \pm 0,05^{\mathrm{a}}$ & $1,91 \pm 0,06^{\mathrm{b}}$ \\
\hline Phosphorus (mg) & $80,61 \pm 1,90^{\mathrm{a}}$ & $88,54 \pm 1,48^{\mathrm{b}}$ \\
\hline
\end{tabular}

Similar letters in a row symbolize statistically significant difference $(\mathrm{p}<0.05)$

Average \pm standard deviation

The percentage of protein in both samples was higher than the minimum required by Decree 1880 of 2011[20], which states that raw milk must have a minimum of 2.9\% protein. The percentages obtained here were higher than those shown in other investigations [21]-[24].Fat percentage results for both municipalities were lower than those shown by Granados et al., [14], Meurer et al., [25] and Lima et al., [26] and higher than those shown by Martínez y Gómez [24] and Ceballos et al., [22]. With respect to the percentage of moisture, no 
significant difference was found between the samples, and it was similar to the percentages shown by Bylund[27] and Revilla [28].

The percentage of ashes showed differences $(\mathrm{p}<0.05)$ and these data are lower than those shown by Meurer et al., [25]. In terms of total solids, no statistically significant difference was found; moreover, these were higher than required by NTC 399[19] and Calderón et al., [29].Likewise, the evaluated minerals (Ca, Zn, and P) are observed that there is a statistical difference between the two analyzed samples, zinc is within the range of 0.42$3.90 \mathrm{mg}$ exposed by Revilla [28], while calcium and phosphorus were lower than that exposed by the same.Bernal et al., [30] and CANILEC [31] mention that the breed, feeding of cows and lactation status, as well as time of year (winter and summer) are some of the variables that may affect the parameters evaluated in this research.Table 2 shows the physicochemical results of the cheese in the municipalities evaluated.

Table II. Physicochemical results of the Queso Costeño produced in Villanueva and Santa Rosa

\begin{tabular}{|l|c|c|}
\hline Type of test & Villanueva & Santa rosa \\
\hline Protein (\%) & $21.92 \pm 0.31^{\mathrm{a}}$ & $18.46 \pm 0.42^{\mathrm{b}}$ \\
\hline Fat (\%) & $28.92 \pm 0.13^{\mathrm{a}}$ & $28.00 \pm 0.21^{\mathrm{a}}$ \\
\hline Moisture (\%) & $45.39 \pm 0.67^{\mathrm{a}}$ & $49.21 \pm 0.46^{\mathrm{b}}$ \\
\hline Ash (\%) & $1.41 \pm 0.01^{\mathrm{a}}$ & $3.17 \pm 0.05^{\mathrm{b}}$ \\
\hline Total solids (\%) & $54.61 \pm 0.67^{\mathrm{a}}$ & $50.79 \pm 0.46^{\mathrm{b}}$ \\
\hline Calcium (\%) & $0.52 \pm 0.03^{\mathrm{a}}$ & $0.49 \pm 0.01^{\mathrm{a}}$ \\
\hline Zinc (m) & $3.62 \pm 0.04^{\mathrm{a}}$ & $3.54 \pm 0.06^{\mathrm{a}}$ \\
\hline Phosphorus (mg) & $81.52 \pm 0.54^{\mathrm{a}}$ & $80.89 \pm 0.33^{\mathrm{a}}$ \\
\hline
\end{tabular}

Similar letters in a row symbolize statistically significant difference $(\mathrm{p}<0.05)$

Average \pm standard deviation

With regard to the physicochemical analyses of Queso Costeño (Table 2) in both municipalities, it can be observed that there was a significant difference between the analyses in both municipalities except for the phosphorus content.The percentage of protein for the municipality of Villanueva was higher than those shown Jiménez et al., [18] and Ballesta[17], while this same parameter for the Queso Costeño from the municipality of Santa Rosa was lower than the results shown Ballesta [16] and higher than the 5 treatments made by Jiménez et

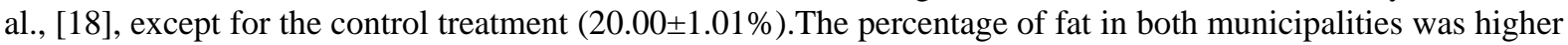
than those shown by Jiménez et al., [18], Morales et al., [32], Ballesta [17], Chaves and Romero [16] and lower than that reported by López-Tenorio et al., [33] (31.0 $\pm 1.41 \%$ ). The moisture percentage of the QuesoCosteño of the two municipalities was higher than those reported by Chaves and Romero [16], López-Tenorio et al., [33] and Morales et al., [32], while it was lower than that shown by Jiménez et al., [18] and Ballesta [17], Therefore, it can be considered that cheeses made in the municipalities evaluated have less susceptibility to microorganisms than cheeses with a higher moisture content, given that high levels of this favour the growth of microorganisms [34].

Table III. Physicochemical results of Suero Costeño produced in Villanueva and Santa Rosa

\begin{tabular}{|c|c|c|}
\hline Type of test & Villanueva & Santa Rosa \\
\hline Protein (\%) & $8.82 \pm 0.05^{\mathrm{a}}$ & $7.84 \pm 0.15^{\mathrm{b}}$ \\
\hline Fat (\%) & $13.38 \pm 0.40^{\mathrm{a}}$ & $12.19 \pm 0.10^{\mathrm{a}}$ \\
\hline Moisture (\%) & $77.53 \pm 0.29^{\mathrm{a}}$ & $78.06 \pm 0.09^{\mathrm{b}}$ \\
\hline Ash (\%) & $1.40 \pm 0.02^{\mathrm{a}}$ & $1.82 \pm 0.05^{\mathrm{b}}$ \\
\hline Total solids (\%) & $22.47 \pm 0.29^{\mathrm{a}}$ & $21.94 \pm 0.09^{\mathrm{b}}$ \\
\hline Calcium (\%) & $0.37 \pm 0.01^{\mathrm{a}}$ & $0.36 \pm 0.011^{\mathrm{a}}$ \\
\hline Zinc (mg) & $1.31 \pm 0.03^{\mathrm{a}}$ & $1.25 \pm 0.089^{\mathrm{a}}$ \\
\hline Phosphorus (mg) & $60.44 \pm 0.85^{\mathrm{a}}$ & $61.00 \pm 1.34^{\mathrm{a}}$ \\
\hline
\end{tabular}

Similar letters in a row symbolize statistically significant difference $(\mathrm{p}<0.05)$

Average \pm standard deviation

According to the percentages of moisture and fat, it can be said that the cheeses evaluated in accordance with the Colombian Technical Standard 750[35]are considered semi-hard and fatty. The ash and total solids content of the evaluated cheeses was lower and higher than that reported by Ballesta[17], respectively.In terms of calcium, zinc and phosphorus content no significant differences were found between the samples. The statistically significant differences between samples could be due to differences in processing methods, since 
Villanueva cheese after mechanical pressing is manually compressed to remove the remaining whey or espiche, which removes moisture and concentrates total solids and proteins.

In the physicochemical analyses of Suero Costeño (Table 3), no statistically significant difference was found for fat, zinc and phosphorus parameters. The protein content of the Suero Costeño from Villanueva was greater than 5.09\% of Montería shown by Simanca et al., [36] and was lower than the Suero Costeño of the municipality of Santa Rosa and Carmen de Bolívar (7.60\%), Arjona (7.39\%), Turbaco (7.38\%) and processor (7.60\%) reported by Granados et al., [14] and what was shown by González et al., [15] in the municipalities of Magangué (7.55\%),Malagana (7.63\%) and Mahates (7.47\%), all of them in the department of BolívarColombia. As for the percentage of fat presented by both municipalities was greater than the $9,40 \%$ presented by Granados et al., [14] and 0.49\%, 3.41\% and 3,29\% presented by González-Moreloet al.,[15] and in the humidity percentage was higher than 76,03\% obtained by Simancaet al.,[36]. Both samples evaluated for having a percentage of fat higher than $10,9 \%$ are considered as fatty Suero Costeño according to Chamie and Garcia [9], and were found to be within the range of $2.7 \%$ and $28 \%$ expressed by Acevedo et al., [11]. The percentage of ashes evaluated in this research was less than $2.85 \%$ shown by Granados et al., [14] and 2.88\% by Simanca et al., [36]. As for the percentage of total solids was below the average expressed by Acevedo et al., [11] which is $32.01 \%$, this low percentage can contribute to the increase in the percentage of syneresis, since this is one of the parameters that help to increase or decrease the percentage of syneresis[37]-[39].

For calcium, zinc and phosphorus there was no statistically significant difference between the samples. The significant differences in the percentages of protein, moisture and total solids, is due to the addition of fragments of Queso Costeño to the Suero Costeño in the municipality of Villanueva during the preparation of the latter, which makes the above-mentioned parameters increase.

\section{CONCLUSION}

The selected raw milk they use for direct consumption and for the production of Queso Costeño and Suero Costeño in the municipalities of Villanueva and Santa Rosa in the Department of Bolívar-Colombia complied with all the physicochemical parameters established by Colombian standards.Differences between the assessed samples of raw cow's milk were due to, among other reasons, feeding, breeds and climate of the cows. The Queso Costeño and Suero Costeño from the municipality of Villanueva presented lower results in the parameters of protein, moisture and total solids, the statistical differences were due to differences in the production procedures of Suero costeño and Quesocosteño in the research municipalities.

\section{REFERENCES}

[1] FAO/OMS, “Leche y productos lácteos,” Roma, Italia: Comisión del Codex Alimentarius (Organización de las Naciones Unidas para la Agricultura y la Alimentación (FAO) y Organización Mundial de la Salud (OMS)), 130 p,2001.

[2] R. Arango, "La electrocoagulación: una alternativa para el tratamiento de aguas residuales,” Revista Lasallista de Investigación, vol. 2, no. 1, pp. 49-56, 2012.

[3] L. Chams, K.Curyand Y. Aguas, "Evaluación microbiológica de suero costeño y valoración higiénica en puntos de venta en montería, córdoba,"Revista Colombiana de ciencia Animal, vol. 4, no. 2, pp. 344-352, 2012.

[4] DNP - Departamento Nacional de Planeación, "Estudio para la identificación de los productos potenciales en los sectores agropecuarios, agroindustrial y artesanal, que podrían ser protegidos a través de denominaciones de origen, marcas colectivas o de certificación,” Available in: https://colaboracion.dnp.gov.co/CDT/Desarrollo\%20Empresarial/propiedad_intelectual.pdf, 2011.

[5] J. Serpa-Fajardo, R. Torres-Gallo and E. Montes-Montes, "Efectos de las condiciones del proceso en los parámetros texturales del queso costeño pasteurizado,”Agronomía Colombiana, vol. 34, 1Supl., S652-S654, 2016.

[6] J. Díaz, "Caracterización del mercado de la industria quesera en la subregión Valle del Ariguaní, Departamento del Magdalena,’Undergraduatethesis,Faculty of AgriculturalSciences,University of la Salle, Bogotá-Colombia, 2009.

[7] G. Espinal and S. Barrera, "Inventario y desarrollo de la tecnología de productos lácteos campesinos en Colombia,” ICTA, Bogotá, Colombia, 2000.

[8] K. González-Morelo, D. Acevedo, L. Fuentes and D.F. Tirado, “Queso Costeño,” In: Productos Lácteos Autóctonos del Caribe Colombiano. Casa Editorial S.A, Cartagena, Colombia, pp. 127-133, 2016

[9] Q. Chamieand O. García, “Caracterización fisicoquímica del suero costeño,”Undergraduatethesis, University of la Sabana. BogotáColombia, 1999.

[10] C. Cueto, D.García, F.Garcésand J.Cruz,"Preliminarystudiesonthemicrobiologicalcharacterization of lacticacid bacteria in Suero costeño, a Colombiantraditionalfermentedmilkproduct,” Revista latinoamericana de microbiología, vol. 49, no. 1-2, pp. 11-17, 2007.

[11] D. Acevedo, A. Rodríguez and A. Fernández, "Determinaciones de flujo del suero costeño con diferentes concentraciones de sólidos totales,” Biotecnología en el Sector Agropecuario y Agroindustrial, vol. 10, no. 2, pp. 18-24, 2012.

[12] D. Acevedo, C. Granados and R. Torres, "Caracterización reologica del suero costeño de Turbaco, Arjona, El Carmen de Bolívar y uno Comercial (Colombia),” Información Tecnológica, vol. 25, no. 3, pp. 3-10, 2014.

[13] D. Acevedo, J. Torres, D. Tirado, J. Ramírez, K. González, E. Castillo, M.Torrenegra, C. Granados, G. Urbina and L. Fuentes, "Productos lácteos autóctonos del Caribe colombiano," Casa editorial S.A. Cartagena de Indias-Colombia, 2016.

[14] C. Granados, D. Acevedoand R. Torres, "Calidad de la leche y del suero costeño de los municipios Turbaco, Arjona y Carmen de Bolívar - Colombia,”Revista Lasallista de Investigación, vol. 9, no. 2, pp. 132-137, 2012.

[15] K. González-Morelo, J. Colina, D. Tirado, D. Acevedo and R. Torres, "Caracterización fisicoquímica del suero costeño de los municipios Magangué, Mahates, Malagana- Bolívar, Colombia,” $2^{\text {do }}$ congreso colombiano de estudiantes de ingeniería de alimentos, Medellin-Colombia, pp. 101-103, 2015.

[16] A. Chaves and A. Romero, "Diagnóstico de las condiciones microbiológicas y fisicoquímicas del queso costeño producido en el municipio de Sincé-Sucre (Colombia),”Undergraduatethesis,Faculty of Engineering, University of Sucre, Sincelejo-Colombia, 2006. 
[17] I. Ballesta, "Evaluación de la calidad del queso costeño elaborado con diferentes tipos de cuajo (animal y microbiano) y la adición o no de cultivos lácticos (Lactococcuslactissubps. lactis y Lactococcuslactissubps. cremoris), "Master'sthesis. Faculty of AgriculturalSciences, University Nacional de Colombia Sede Medellín, Medellín-Colombia, 2014.

[18] A. Jiménez, J. Betancourt, J. Serpa, L. Contreras and O. Salgado, "Evaluación de cultivos (St. thermophilusyLb. bulgaricus) sobre parámetros de calidad del queso costeño,”Agronomía Colombiana, vol. 34, 1Supl., S1261-S1263, 2016.

[19] NTC - Norma Técnica Colombiana 399, "Productos lácteos. Leche cruda,”Bogotá. ICONTEC, 2002.

[20] Ministerio de Protección social, Decreto 1880, "Por el cual se señalan los requisitos para la comercialización de leche cruda para consumo humano directo en el territorio nacional,” Colombia, 2011.

[21] D. Kapadiya, D.Prajapati, A. Jain, B. Mehta, V.Darji, and K.Aparnathi,“Comparison of Surti goat milk with cow and buffalo milk for gross composition, nitrogen distribution, and selected minerals content,”Veterinary World, vol.9, no. 7, pp. 710-716, 2016.

[22] L. Ceballos, E. Morales, G. de la Torre, J. Castro, L.Martínezand M.Sampelayo,"Composition of goat and cow milk produced under similar conditions and analyzed by identical methodology,”Journal of Food Composition and Analysis, vol.22, no. 4, pp. 322-329, 2009.

[23] D. Agudelo and O. Bedoya, “Composición nutricional de la leche de ganado vacuno,” Revista Lasallista de Investigación, vol. 2, no. 1, pp.38-42, 2005.

[24] M. Martínez and C. Gómez,“Calidad composicional e higiénica de la leche cruda recibida en industrias lácteas de sucre, Colombia,” Biotecnología en el Sector Agropecuario y Agroindustrial, vol. 11, no. 2, pp. 93-100, 2013.

[25] T. Meurer, F. Picinin, P. Manique, H. Domingosand E.Schwinden, "Avaliação físico-química, microbiológica e reológica de bebida láctea e leite fermentado adicionados de probióticos,”Semina:Ciências Agrárias, vol. 29, no. 1, pp. 103-116, 2008.

[26] F. Lima, R. De Paula, M. Coelho, S. Cardosoand L. Vargas, "Produção e Composição do Leite de Vacas Submetidas a Dietas Contendo Diferentes Níveis e Formas de Suplementação de Lipídios,”Revista brasileira de zootecnia, vol. 30, no. 4, pp. 1376-1380, 2001.

[27] G. Bylund,“Manual de industrias lácteas,”Firstedition. Madrid-España, 1996.

[28] A.Revilla,“Tecnología de la leche: procesamiento, manufactura y análisis,”SecondEdition. IICA. San José - Costa Rica,1982.

[29] A. Calderón, V. Rodríguez and S. Vélez,"Evaluación de la calidad de leches en cuatro procesadoras de quesos en el municipio de Montería, Colombia,”Revista MVZ Córdoba, vol. 12, no. 1, pp. 912-920, 2007.

[30] L. Bernal, M. Rojas, C. Vázquez, A. Espinoza, J. Estrada and O. Castelán,"Determinación de la calidad fisicoquímica de la leche cruda producida en sistemas campesinos en dos regiones del Estado de México,” Veterinaria México, vol. 38, no. 4, 395-407, 2007.

[31] CANILEC,“El libro blanco de la leche y los productos lácteos,”Firstedition, México D.F.- México,2011.

[32] M. Morales, E. Rodríguezand J. Sepúlveda,“Evaluación de las propiedades físicas y texturales del buñuelo,”Revista lasallista de investigación, vol. 9, no. 2, pp. 112-121, 2012.

[33] J. López-Tenorio, E. Rodríguez-Sandovaland J. Sepúlveda-Valencia,“Evaluación de características físicas y texturales de pandebono,” Acta Agronómica, vol. 61, no. 3, pp. 273-281, 2012.

[34] Y. Park,"Moisture and sodium levels in commercial goat cheeses compared with cow cheeses,"Small Rumiant Research, vol. 5, pp. $141-148,1991$.

[35] NTC - Norma Técnica Colombiana 750,“Productos lácteos. Queso”Bogotá. ICONTEC, 2000.

[36] M. Simanca, M. Arteaga, Y. Pérez, M. Soto and J. Salcedo,“Caracterización y estudio de la fermentación espontánea del suero costeño producido en Montería,” Revista MVZ Córdoba, vol. 15, no. 1, pp. 1944-1953, 2010.

[37] D. Acevedo, A. Rodríguez y A. Fernández,"Efecto de las variables de proceso sobre la cinética de acidificación, la viabilidad y la sinéresis del suero costeño colombiano,” Información Tecnológica, vol. 21, no. 2, pp. 29-36, 2010.

[38] D. Acevedo, A. Rodríguez and A. Fernández,"Determinaciones oscilatorias de baja amplitud del suero costeño,” Revista U.D.C.A Actualidad \& Divulgación Científica, vol. 15, no. 1, pp. 219-225, 2012.

[39] D. Acevedo, A. Rodríguez and A. Fernández,“Efectos simultáneos de las variables de proceso sobre las propiedades de flujo del suero costeño,” Biotecnología en el Sector Agropecuario y Agroindustrial, vol. 11, Edición Especial 2, pp. 112-117, 2013. 